\title{
CIDR: A Small \\ Service Firm Within a Research University
}

\author{
Jody D. Nyquist
}

University of Washington

As readers of this article well know, instructional and faculty development programs differ in amazing ways across the country. Some units are housed in central administration, report to a Provost or Vice President, and are financed from a University operating budget. Some are outgrowths of state legislation with special funding, and others are self-sustaining, entrepreneurial endeavors. Some units are staffed by one person only, while others may employ 20 to 25 people. The tremendous diversity makes it difficult to write an article that will be useful to the varied readers whose worlds may be very similar or very different. We hope that sharing our experience at the University of Washington will provide some new ways of thinking about instructional development issues and/or enable you to select some ideas which could be modified for your own use. We will rely on you to make the links or applications appropriate for your particular institution.

\section{BASIC ASSUMPTIONS UNDERLYING CIDR'S INSTRUCTIONAL DEVELOPMENT PROGRAM}

\section{Must Reflect Culture and Values of Institution}

To begin with, our Center for Instructional Development and Research (CIDR) operates on the basis of two very obvious, but often overlooked, assumptions about instructional and 
faculty development. First, we believe that an effective instructional faculty and development program must reflect the culture and values of the institution in which it resides. In our particular instance that means that we must work with instructors $(3,500$ faculty and 1,000 graduate teaching assistants $)$ who are dedicated, in addition to teaching, to producing a very high quality of research in every discipline. The University of Washington has consistently placed among the top five institutions in the nation in the amount of federal research monies received. We are the largest research institution in the Northwest which includes the states of Oregon, Montana, Idaho, Northern California, and Alaska. Thus, this means that research dominates faculty interests and therefore attention given to teaching must be discipline-oriented and require only a limited investment of time from the individual faculty member or department. It means also that CIDR must carry on research itself in order to be credible in the eyes of its clients (the professors and instructors in each of the departments).

Organizationally, the University is hierarchical yet at the same time democratic and dependent on faculty agreement in many areas. The departments themselves, some 90 of them, are very autonomous, led by chairs, who, working with the various deans, have final authority. At the same time, faculty members (both individually and collectively) exert substantial influence on most decisions. Our administrators are dedicated primarily to responding to what the professors of this large institution desire. While central administration is very supportive of improvement of instruction, there are no central decrees from which CIDR can obtain authority. This means that CIDR must become, on its own merits, an invaluable resource to individual faculty members and department chairs since using our services is not required of anyone.

\section{Must Help Faculty}

Our second basic assumption about an instructional and faculty development program is that it ought to help people. While this comment usually brings a "guffaw" and "well, obviously," we would suggest that some faculty development programs do not do so on a practical day-to-day basis. Our goal is to make a measurable difference in the daily teaching lives of our instructors, which results in our being extremely applied 
problem solvers. We do what faculty ask us to do; we attempt to solve the instructional problems that cause them the most frustration. Only after that do we attempt to attack other instructional issues. For example, we may be asked to assist an instructor who has received student evaluations indicating that she is perceived to be disorganized. She is certain it is because of her lectures. We interview students who describe her written assignments as confusing. She is not convinced so we videotape and work with her on improving her lecture until she is satisfied with her performance. Only after that do we assist in restructuring her written assignments. We believe instructors must "own" their instructional improvement efforts. We help them with issues they perceive to be important. We provide services that our clients want.

This suggests that CIDR must devise ways of using the "currency" which is of greatest value to faculty. We are forced, therefore, to look for other incentives. Our university does not provide release time, instructional development leaves, or instructional mini-grants for our instructors. We try to enable faculty to save time, procure positive student evaluations, obtain positive tenure and promotion decisions, etc. We operate on the basis of offering these items as incentives for faculty improvement efforts.

\section{GOALS OF THE CENTER FOR INSTRUCTIONAL DEVELOPMENT AND RESEARCH}

Given these two basic assumptions we have developed what we call a discipline-specific philosophy. CIDR staff believe in the integrity of subject matter. We believe that the way academics stimulate inquiry, generate knowledge and present understanding is greatly influenced by a discipline. The responsibilities of Center personnel are to act as catalysts to stimulate departments to undertake instructional improvement efforts. Center staff work together to provide services, to conduct research projects on learning and teaching, and to publish materials on instructional improvement in order to assist departments in their efforts.

The primary purpose of the Center of Instructional Development and Research is to encourage and support improvement of teaching and learning at the University of Washington. Representing a part of the University's commitment to 
excellence in teaching, the Center operates as an active instructional resource clearinghouse to provide comprehensive assistance to the teaching scholars of this institution.

\section{CIDR AS A SMALL SERVICE FIRM}

Given this basic philosophy and the Center's goal, we soon realized that we were primarily a service organization. In fact, we began to see ourselves as a small service firm in the midst of an enormous institution. This led us to look at other service firms from which we might borrow some ideas while being constantly vigilant about reflecting the values and culture of our institution. In reviewing service firm literature, we became interested in a number of ideas which seemed very appropriate to adopt. According to the experts, some of the keys to successful service firms are:

1 . The service must meet the specific needs of potential customers.

2. Effective service depends on the quality of the face-to-face encounters between customers and employees of the firm.

3. A successful service firm is highly visible.

4. Successful service firms systematically monitor customer satisfaction.

These ideas guided our evolution over the last two and a half years and permeate our organizational structure, staffing, and decision making.

\section{Meeting the Needs of Clients}

To begin with, we have always been customer-oriented. We see our customers or clients as all instructors at the University of Washington, which includes graduate teaching assistants, instructors, lecturers, teaching associates and professors of all ranks. We wanted to focus on what they wanted or needed in terms of instructional assistance. To identify .what that was, we began by interviewing a wide range of university personnel -representatives of all the instructional staff, deans, department chairs, provosts and others - as to what each one felt an organization such as ours could offer the instructional staff of a major research university. Every interview brought us new 
insights and new information, which finally resulted in the development of a wide range of CIDR services. It also taught us the value of being out in the departments all the time rather than expecting people to come to the Center.

The Director for Instructional Development attempts to call on the chairs of all departments on campus every two years to determine what instructional needs exist at the departmental level. To facilitate that interview, we developed a Departmental Instructional Profile, which has become an invaluable tool for assessing those needs and for establishing an instructional activity data base for the campus. Our current form is displayed in Appendix A.

The Departmental Instructional Profile attempts to describe a department solely on the basis of instructional dimensions. The Center staff collects available instructional data regarding class size, number of majors, ratio of instructors to students, student rating means by instructor rank, recognition of teaching excellence, number of student course drops, grade distributions, existence of curriculum committees, distinguished teaching recipients, etc. as indicated on the form. This allows the Director for Instructional Development to identify with the department chairperson those aspects of instruction in which the department takes great pride and can share with the rest of the university community. It is also an opportunity to determine those aspects of the instructional product where the chairperson feels additional work is required. This information is then brought back to an Instructional Development Specialist in the Center who identifies which staff member can most ably assist the department given whatever need has been suggested.

When the Center assists entire departments, a workshop and/or research project is designed for that specific discipline. For example, if a number of faculty in a department are concerned about teaching students to think critically, they may request that Center staff present a workshop on student problem solving in that particular discipline. Sometimes departments have courses that are creating difficulties for them. They may request research assistance to make recommendations for restructuring the courses. In all instances, the Center attempts to tailor the workshops or research projects for that specific department. All presentations from CIDR staff require extensive preassessment with department representatives. Specific 
examples from the discipline are utilized in all cases. Given CIDR's discipline specific philosophy, we do not offer generic workshops.

An additional tool we have developed which has become very useful to us is an Instructional Interest Inventory with separate forms for instructors and for graduate teaching assistants. Departments can either administer the inventory to their own faculty or have it administered by CIDR. It is displayed in Appendix B. In this way we can identify the major needs of individuals and departments in terms of instructional improvement. Again, this information is given to the staff person who is working with the specific department for follow-up.

On the basis of the Instructional Interest Inventories, we are working toward creating a comprehensive instructional data base so that any instructor may come to CIDR, sit down at one of our micro-computers, respond to the Instructional Interest Inventory and procure a printout which will tell him or her what instructional improvement resources are available on campus. For example, if an instructor is interested in learning how to lead discussions more effectively, we would anticipate that the printout would provide a list of printed material available in CIDR, a list of media dealing with leading discussions including video and/or audio tapes, and instances in the university community where professors are particularly effective at leading discussion and are willing to be observed. Once that data is available to an instructor, then it can be used on an individual basis for a CIDR consultation.

Some instructors have special needs such as the use of computers in their teaching. For these reasons the Center maintains a microcomputer laboratory with workstations fully equipped with graphics, interactive videodiscs, and extensive networking capabilities to enable instructors to integrate computers into their instruction. Again Center staff work on an individual basis to assist instructors to develop specific computer applications useful for the teaching of their particular discipline.

\section{Creating The Service Encounter-CIDR Staff and Instructors}

As other service firms report, effective service depends on the quality of the face-to-face encounters between clients and employees. We are a people-to-people operation, and the 
countless interactions between staff and clients must, for the most part, go unmonitored by the Directors. From support staff to consultants, to student assistants, to directors, we stress that every encounter determines whether or not that person returns to the Center or recommends that others seek our services. When a phone call comes into our Center, it is answered by our most knowledgeable person who is able to assist the caller immediately, log the request, make the referral and check on follow-up. Every call is returned as soon as possible. A biweekly staff meeting of our 21 part and full time members is dedicated to status reports, requests for contacts, evaluation of ideas for various projects, etc., with the primary goal of keeping everyone advised of what is happening on the various projects so that all can be active marketers for the Center. All staff represent the Center, and they must be effective in explaining to others the philosophy, goals, and specific projects undertaken by CIDR.

Staff members are given extensive training in consulting skills because a great deal of time is spent in consultation. For example, a faculty member may be concerned about his/her approach to lecturing or discussion, or an instructor may want help interpreting a set of student ratings that he/she has received. In any of these cases, Center staff consult with the instructor to determine the particular needs and choose an appropriate form of assistance. In some instances, the faculty member may be given written material from the CIDR library referencing a collection of articles, conference papers, and technical reports on all aspects of effective teaching and educational research in higher education. The library is maintained as a center resource, open to all faculty and TA's.

In other instances, the faculty member may prefer videotape consultation. Another popular service requested by individual faculty members is a type of class interview called the small group instructional diagnosis (SGID). This process uses small group discussion in the middle of the quarter to elicit feedback from students.

In some cases, consulting is a matter of providing assistance in developing course syllabi or writing assignments and exams. Whatever the approach, all faculty consultations are customized for the individual instructors and in the end, our entire operation rests in the hands of the staff who sit down with individual instructors to create and deliver any instructional service. This 
service encounter determines the acceptance of and implementation of instructional change.

\section{Establishing High Visibility}

A successful service firm is extremely visible. We have worked diligently to become visible. Using interviews, brochures, and customized stationery, we have sought to make our logo and services recognizable throughout the campus. We have exerted a concerted effort to mark everything going out of the office with a highly recognizable coversheet. All reports, requests for evaluation, and other materials are packaged in distinctive CIDR covers and packets. We have produced an extensive but easily readable Annual Report each year which we have distributed to all Deans and Department Chairs.

Many of the instructional efforts of the Center require resource materials that are not readily available. Consequently, the Center is engaged in producing specialized publications, videotapes, and other media for these purposes. For instance, CIDR has produced publications to assist faculty and graduate teaching assistants in interpreting student ratings. Center staff also revised and published Mentor, the University handbook for graduate teaching assistants. Recent Center videotapes include "Distinguished Teachers on Teaching" and "The Role of the Graduate Teaching Assistant." Each of these is packaged in highly recognizable CIDR labels. We have developed brochures and widely advertised their availability.

We send numerous specifically targeted mailings each year. We attempt to address all instructors individually rather than rely on general university-wide service announcements. Besides targeting by individual scholar/teacher and departments, we also focus on new faculty and international teaching assistants as special need groups.

While it is difficult to measure the impact of these efforts, we have experienced a significant change in peoples' awareness of the existence of the Center. No longer do we hear the question, "What is CIDR?" We are constantly adding new faculty and graduate students to our client lists and receive referrals from Deans who have read our Annual Report. 


\section{Monitoring Client Satisfaction}

We ask "users" of any and all of our services, whether ar individual or a department, to assess their satisfaction with CIDR services. Included in Appendix $\mathrm{C}$ are two evaluation instruments we have found useful. Compulsively, we gather such feedback, analyze it, and modify our services accordingly. We believe that our instructors know best what kinds of help will be most beneficial to them. In turn, we are constantly providing them with a range of CIDR service options from which to choose.

\section{CIDR's INSTRUCTIONAL IMPROVEMENT MODEL}

Our small service firm approach has provided us with an operations plan for enabling the Center to offer valuable, clientcentered services. Our goal is to assist instructors and departments to improve the quality of undergraduate education at the University of Washington. As diagrammed below, in all situations, we attempt to analyze instructional needs, provide alternatives, assist with implementation strategies, and assess results. We never lose sight of the importance of meeting needs of clients, providing quality consultation in our service encounters, attempting to be highly visible, and monitoring client satisfaction in order to modify the services we offer.

CIDR staff attempts to act as catalysts for instructional improvement but only in partnership with instructors who are teaching specific disciplines. We believe that we know a lot about teaching, but we do not know more about teaching chemistry, for instance, than chemistry professors do. We can assist them in that task and that is our overall goal.

At this point, we've given two-and-a-half years of our lives to this project. We know we have made a difference at the University of Washington, and we are committed to our service firm orientation. Our clients come from referrals, and the number of repeat consultations is extremely high. We are convinced that our instructors want to be effective in the classroom and that they will accept our assistance if it comes in ways which they can effectively use without their involvement requiring excessive time commitments. We know that the particular design and operation of our Center works 
at our institution. We hope that it will provide some ideas useful for your efforts in your institution.
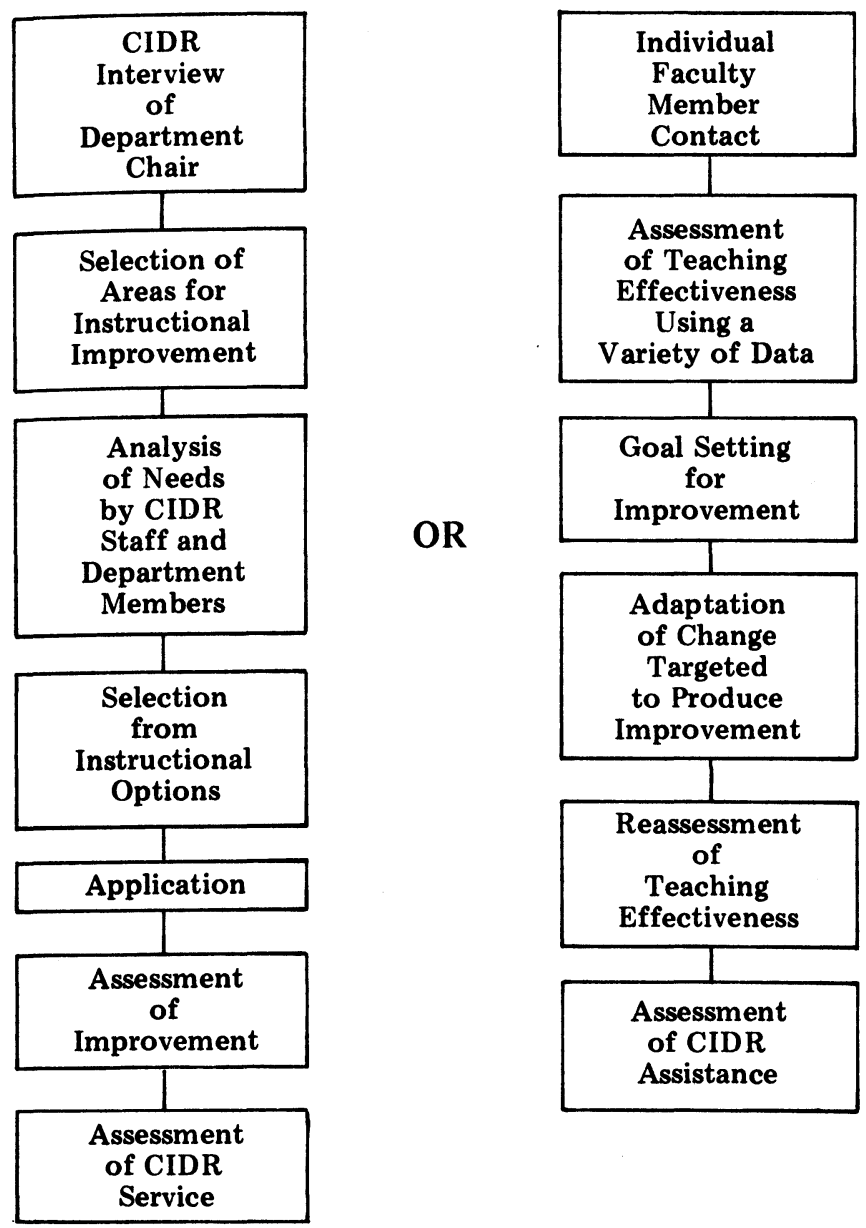


\section{APPENDIX A \\ Center for Instructional Development and Research University of Washington}

Departmental Instructional Profile for [Department Name] :

*1. Number of majors and growth pattern over last few years:

*2. Number of students taking courses in department:

*3. Grade distribution:

Gradepoint requirement for majors:

Distribution by level:

$\begin{array}{ll}100 & 300 \\ 200 & 400\end{array}$

*4. Undergraduate class sizes and formats:

SIZE LEVEL LECTURE QUIZ LAB SEMINAR PRACTICUM \& INDEP. STUDY

$1-20$

$21-50$

$51-75$

$76-100$

101-199

200-299

300-399

400-499

Over 500

Totals

*5. Distribution of instructors by rank, student to instructor ratios. Professors Assoc. Professors Assist. Professors Instructors Lecturers Emeritus

Subtotal:

TA's: Number of ITA's:

Total including TA's:

*6. Student to teaching staff ratios.

Ratio of majors to teaching staff:

Ratio of total enrollment to teaching staff:

*Data gathered before interview. 
*7. Student ratings percentiles:

RANK MEAN NUMBER OF CLASSES

All University

All College

Department:

Professor

Assoc. Professors

Assist. Professors

Instructors

Lecturers

TA's

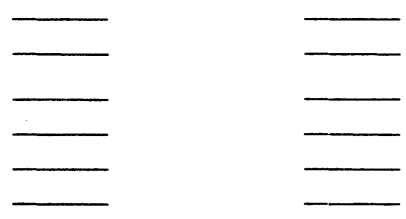

How are student ratings used in your department? Are they required? Does the department recommend other teacher evaluation processes? How do you document a faculty member's teaching effectiveness?

8. Level of TA Training:

*Faculty coordinator:

Ongoing Supervision:

Tasks TA's perform:

Levels and types of courses involving TA's:

9. Number of applicants for programs in department:

10. Number of Distinguished Teaching Awards:

National:

*University of Washington:

Departmental:

11. Past departmental documentation of teaching performance:

How is quality teaching rewarded?

*12. Educational Assessment Center usage figures:

13. Current departmental instructional improvement efforts:

Instructional Development Committee?

Curricular and Course Sequence Decision Making:

How handled? How satisfied with process?

Undergraduate-

MA-

Ph.D.-

14. Individual faculty instructional projects: 
15. Advising:

How handled?

Satisfaction level:

16. Number of drops:

Drop rate:

17. CIDR usage:

18. Exit Surveys/Interviews; Employer Surveys/Other Feedback on instructional preparation of students (Undergrad, MA, Ph.D.):

19. Number of courses which currently require some student work with computers and approximate enrollment figures:

20. What is the number of microcomputers that you currently have in the department that can be used for instruction? How about the number of terminals to minis or mainframes that can be used for instruction? What other access to computers does the department have? For faculty? For students?

21. How many of the courses that require students to use computers, primarily require students to use those computers outside of class time?

22. How many of the courses currently have faculty using computers in the classroom to develop concepts and promote discussion?

23. Which faculty would be interested in working with the Center to develop CAI applications for courses in your department?

*24. How many $\mathrm{W}$ courses does the department offer? Who teaches them? Any special training involved?

*Data gathered before interview. 


\section{APPENDIX B}

\section{Center for Instructional Development and Research University of Washington}

Department/Instructor Name

\section{Faculty Instructional Interests Assessment}

This form is to help you think about various aspects of teaching your discipline. Read and respond by answering the following two questions about each item.

In your opinion, how important is this skill in the teaching of your discipline?

How interested are you in receiving further information in this area?

$\begin{array}{lllllll}\text { Not very important } & 1 & 2 & 3 & 4 & 5 & \text { Very important } \\ \text { Not very interested } & 1 & 2 & 3 & 4 & 5 & \text { Very interested }\end{array}$

\section{COURSE PLANNING}

1. Identifying course goals:

$\begin{array}{lllllll}\text { Not very important } & 1 & 2 & 3 & 4 & 5 & \text { Very important }\end{array}$

$\begin{array}{lllllll}\text { Not very interested } & 1 & 2 & 3 & 4 & 5 & \text { Very interested }\end{array}$

2. Planning the course:

$\begin{array}{lllllll}\text { Not very important } & 1 & 2 & 3 & 4 & 5 & \text { Very important } \\ \text { Not very interested } & 1 & 2 & 3 & 4 & 5 & \text { Very interested }\end{array}$

3. Writing the course syllabus:

$\begin{array}{llllllll}\text { Not very important } & 1 & 2 & 3 & 4 & 5 & \text { Very important }\end{array}$

$\begin{array}{lllllll}\text { Not very interested } & 1 & 2 & 3 & 4 & 5 & \text { Very interested }\end{array}$

4. Constructing essay tests:

$\begin{array}{lllllll}\text { Not very important } & 1 & 2 & 3 & 4 & 5 & \text { Very important }\end{array}$

$\begin{array}{lllllll}\text { Not very interested } & 1 & 2 & 3 & 4 & 5 & \text { Very interested }\end{array}$

5. Constructing objective tests:

$\begin{array}{lllllll}\text { Not very important } & 1 & 2 & 3 & 4 & 5 & \text { Very important }\end{array}$

$\begin{array}{lllllll}\text { Not very interested } & 1 & 2 & 3 & 4 & 5 & \text { Very interested }\end{array}$

\section{GRADING}

6. Grading written work:

$\begin{array}{lllllll}\text { Not very important } & 1 & 2 & 3 & 4 & 5 & \text { Very important }\end{array}$

$\begin{array}{lllllll}\text { Not very interested } & 1 & 2 & 3 & 4 & 5 & \text { Very interested }\end{array}$

7. Grading tests:

$\begin{array}{lllllll}\text { Not very important } & 1 & 2 & 3 & 4 & 5 & \text { Very important }\end{array}$

$\begin{array}{lllllll}\text { Not very interested } & 1 & 2 & 3 & 4 & 5 & \text { Very interested }\end{array}$ 
8. Grading oral presentations:

$\begin{array}{lllllll}\text { Not very important } & 1 & 2 & 3 & 4 & 5 & \text { Very important } \\ \text { Not very interested } & 1 & 2 & 3 & 4 & 5 & \text { Very interested }\end{array}$

9. Using an alternative grading system (contract grading, criterion referenced grading, mastery learning):

$\begin{array}{lllllll}\text { Not very important } & 1 & 2 & 3 & 4 & 5 & \text { Very important } \\ \text { Not very interested } & 1 & 2 & 3 & 4 & 5 & \text { Very interested }\end{array}$

TEACHING STRATEGIES

10. Leading effective class discussions:

$\begin{array}{lllllll}\text { Not very important } & 1 & 2 & 3 & 4 & 5 & \text { Very important } \\ \text { Not very interested } & 1 & 2 & 3 & 4 & 5 & \text { Very interested }\end{array}$

11. Using the lecture method:

$\begin{array}{lllllll}\text { Not very important } & 1 & 2 & 3 & 4 & 5 & \text { Very important }\end{array}$

$\begin{array}{lllllll}\text { Not very interested } & 1 & 2 & 3 & 4 & 5 & \text { Very interested }\end{array}$

12. Using small groups as a teaching method:

$\begin{array}{lllllll}\text { Not very important } & 1 & 2 & 3 & 4 & 5 & \text { Very important }\end{array}$

$\begin{array}{lllllll}\text { Not very interested } & 1 & 2 & 3 & 4 & 5 & \text { Very interested }\end{array}$

13. Using instructional games and simulations:

$\begin{array}{lllllll}\text { Not very important } & 1 & 2 & 3 & 4 & 5 & \text { Very important }\end{array}$

$\begin{array}{lllllll}\text { Not very interested } & 1 & 2 & 3 & 4 & 5 & \text { Very interested }\end{array}$

14. Using case studies as a teaching method:

$\begin{array}{lllllll}\text { Not very important } & 1 & 2 & 3 & 4 & 5 & \text { Very important }\end{array}$

$\begin{array}{lllllll}\text { Not very interested } & 1 & 2 & 3 & 4 & 5 & \text { Very interested }\end{array}$

15. Using media in instruction:

$\begin{array}{lllllll}\text { Not very important } & 1 & 2 & 3 & 4 & 5 & \text { Very important }\end{array}$

$\begin{array}{lllllll}\text { Not very interested } & 1 & 2 & 3 & 4 & 5 & \text { Very interested }\end{array}$

16. Using computers in instruction:

$\begin{array}{lllllll}\text { Not very important } & 1 & 2 & 3 & 4 & 5 & \text { Very important }\end{array}$

$\begin{array}{lllllll}\text { Not very interested } & 1 & 2 & 3 & 4 & 5 & \text { Very interested }\end{array}$

17. Producing instructional videotapes:

$\begin{array}{lllllll}\text { Not very important } & 1 & 2 & 3 & 4 & 5 & \text { Very important }\end{array}$

$\begin{array}{lllllll}\text { Not very interested } & 1 & 2 & 3 & 4 & 5 & \text { Very interested }\end{array}$

CLASSROOM MANAGEMENT

18. Responding to student questioning about course content:

$\begin{array}{lllllll}\text { Not very important } & 1 & 2 & 3 & 4 & 5 & \text { Very important } \\ \text { Not very interested } & 1 & 2 & 3 & 4 & 5 & \text { Very interested }\end{array}$

19. Responding to student challenges over course procedures, grading, policies, workload, etc.:

$\begin{array}{lllllll}\text { Not very important } & 1 & 2 & 3 & 4 & 5 & \text { Very important }\end{array}$

$\begin{array}{lllllll}\text { Not very interested } & 1 & 2 & 3 & 4 & 5 & \text { Very interested }\end{array}$ 
20. Managing large enrollment courses:

$\begin{array}{lllllll}\text { Not very important } & 1 & 2 & 3 & 4 & 5 & \text { Very important }\end{array}$

$\begin{array}{lllllll}\text { Not very interested } & 1 & 2 & 3 & 4 & 5 & \text { Very interested }\end{array}$

21. Handling office hours:

$\begin{array}{lllllll}\text { Not very important } & 1 & 2 & 3 & 4 & 5 & \text { Very important }\end{array}$

$\begin{array}{lllllll}\text { Not very interested } & 1 & 2 & 3 & 4 & 5 & \text { Very interested }\end{array}$

22. Communicating interpersonally with students:

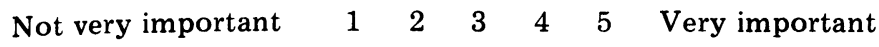

$\begin{array}{llllllll}\text { Not very interested } & 1 & 2 & 3 & 4 & 5 & \text { Very interested }\end{array}$

Are there other areas concerned with teaching in which you would like information? 


\section{APPENDIX C \\ Small Group Instructional Diagnosis (SGID)}

CIDR Staff Name of Client

SGID Administered Department

1. Small Group Instructional Diagnosis (SGID) process was adequately explained.

\section{STRONGLY DISAGREE}

1 2

3

\section{STRONGLY AGREE}

4
5

2. SGID was an appropriate strategy to meet my instructional needs.
1
2
3
4
5

3. Center Staff persons executed the SGID effectively.

$\begin{array}{lllll}1 & 2 & 3 & 4 & 5\end{array}$

4. Center Staff person(s) reported results to me in a clear, concise, useful form.

$\begin{array}{lllll}1 & 2 & 3 & 4 & 5\end{array}$

5. I intend to use the services of the Center in the future Yes No (Please comment on your response.)

6. I would recommend the Center to colleagues Yes No desiring to work on the improvement of teaching. (Please comment on your response.)

7. I would be willing to act as a resource to other Yes No instructors who may be working on similar instructional needs.

ADDITIONAL COMMENTS:

RECOMMENDATIONS TO CENTER STAFF: 
CIDR Staff Person(s) Quarter

Course/Concern Service Provided

1. Center Staff personnel were very effective in understanding your particular instructional needs.

STRONGLY DISAGREE

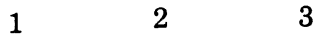
3 STRONGLY AGREE

$\begin{array}{lll}4 & 5 & \mathrm{~N} / \mathrm{A}\end{array}$

2. Center Staff personnel selected or designed an appropriate plan to meet your instructional needs.
1
2
3
4
5
N/A

3. Center Staff personnel executed the plan effectively.
1
2
3
4
5
N/A

4. Center Staff personnel analyzed outcomes of the plan appropriately.
1
2
3
4
5
N/A

5. Center Staff personnel reported results to you in a clear, concise, useful form.

1

2

34

5

N/A

6. I intend to use the services of the Center in the future Yes No (Please comment on your response.)

7. I would recommend the Center to colleagues desiring Yes No to work on the improvement of teaching.

(Please comment on your response.)

8. I would be willing to act as a resource to other

Yes No instructors who may be working on similar instructional needs.

ADDITIONAL COMMENTS:

RECOMMENDATIONS TO CENTER STAFF : 